\title{
Effect of a rotifer and artemia on survival and growth performance of gilthead seabream Sparus aurata larvae.
}

\author{
El Sagheer, Fawzi, H. $^{1}$ and Labib, Eman, M. $^{2}$ \\ 1- Faculty of Agriculture, Sana'a University, Yemen \\ 2- Agriculture Research Center, Burg El-Arab, Alexandria, Egypt
}

\begin{abstract}
An experiment was carried out in order to study the effect of a rotifer Brachionus plicatilis and encapsulated Artemia nauplii as a live food on survival rate and growth performance for gilthead sea bream Sparus aurata larvae. Gilthead sea bream larvae (20 days old) with body length and weight of $(7.3 \pm 0.20 \mathrm{~mm})(5.4 \pm$ $0.10 \mathrm{mg}$ ) respectively, were stocked in eight white fiberglass tanks (each of $1 \mathrm{~m}^{3}$ volume) at a density of 1,200-larvae/ tank. Four treatments were tested as follows, 1) low rotifers and low artemia (LRLA); 2) high rotifers and low artemia (HRLA); 3) low rotifers and high artemia (LRHA); and 4) high rotifers and high artemia (HRHA) for 24 days (5, 25 rotifers and 50, 250 artemia $/ \mathrm{ml}$, during the periods $1^{\text {st }}, 8^{\text {th }}, 9^{\text {th }}, 16^{\text {th }}$, $17^{\text {th }}$ and $24^{\text {th }}$ days of the feeding experiment).

The results showed that the survival rate of S.aurata larvae significantly $(\mathrm{P} \leq$ 0.05) improved with the application of the experimental program by feeding a high mixture of rotifers and artemia. Feeding of higher levels of rotifers and artemia increased the survival rate of $S$. aurata to $48.96 \%$, however, the lower levels of both resulted in only $12.17 \%$ survival rate. Other intermediate treatments of HRLA or LRHA resulted in better improvements in the survival rates (19.08 and 32.21\% respectively) of $S$. aurata larvae. The results clearly showed the significant role of higher levels of encapsulated A. nauplii as a live food for saving the life of $S$. aurata larvae as compared with rotifers.

Values of growth performance of $S$. aurata larvae (gain in length and weight; average daily gain in length and weight; and specific growth rate, (SGR \%) significantly $(\mathrm{P} \leq 0.05)$ increased with increasing the levels of live food from both rotifers and artemia. The results clearly showed the superiority of the higher levels of live artemia in enhancing growth performance of $S$. aurata larvae than rotifers. Finally, a suitable live food program to improve the survival rates of $S$. aurata larvae by feeding high levels of rotifers and artemia could be recommended.
\end{abstract}

Keywords: Rotifers, Artemia, Sea bream, Survival, Growth performance

\section{INTRODUCTION}

Seed production and larval rearing stay very important for all growing operations and considered as the main limiting factors for development of finfish Mari culture (Dhert et al., 1998). Starvation is a major problem for larvae with small reserves of endogenous energy. It is not easy to quantify the nutritional requirements of larval fish. However, it is believed that the optimal formulations for first-feeding larvae should simulate the yolk composition and to some extent reflect the nutrient requirements and metabolic capacities of pre-feeding fish (Heming and Buddington, 1988). The variability of the nutritional value of live foods for marine larval fish is well documented (Watanabe et al., 1980; Bottino et al., 1980; Kuhlmann et al., 1981; and Leger, 1986). The importance of small live preys (organisms) especially rotifers 
and artemia for marine fish hatcheries success has been stressed. Rotifers are valuable live food for larval fish and crustacean culture. Several characteristics of rotifers, including their nutritional quality, body size and relatively slow motility have contributed to their usefulness as good prey for active larvae (Reitan, et al., 1997). The rotifer Brachionus plicatilis has been most widely used as essential food source for raising marine environment (Lubzens, 1987; Dhert et al., 1994). Zaki et al. (2003) showed that the concentration of 16 rotifers per ml of water was optimum for feeding gilthead sea bream $S$. aurata larvae. This concentration in enough to ensure the formation of functional swim-bladder inflation, which improve, the abilities of larval fish for swimming, hunting, feeding, growing, and preventing deformities in fish fry. The rotifer Brachionus plicatilis (S-type Hawaiian strain) was cultured with various combinations of baker's yeast and Nannochloropsis oculata to feed different fish larvae (Clyde et al .,2003).

Artemia nauplius is essential for larval culture of fish hatcheries (Van stappen and Sorgeloos, 1993). Due to its high nutritional value, suitable size, mobility, biochemical composition, A. nauplii has high interest in larval fish culture .In addition, the possibility for improving its nutritional manipulation through enrichment increased the importance of artemia as a live food (Sorgeloos, 1994). There were three main critical phases in intensive rearing of larval sea bream $S$. aurata :a) the end of the larval stage (day 3-4 );b) the endoexotroph stage (day 8-12);c) the larval stage (day 25-35).More than $99 \%$ of the fry were lost during these phases (Dhert et al., 1998)and mean survival was seldom greater than $10 \%$.This low survival was often made worth by cannibalism and abnormalities of marketable fry during nursery operations (Lagos,1989). A new culturing technique using rotifers and artemia as a live foods were developed in Thailand for larval fish production with about $40 \%$ survival rate during the hatchery and nursery phases (Maneewong et al., $1986 \mathrm{a}, \mathrm{b}$ ).

The aim of the present work was to improve the survival rate and growth performance of gilthead sea bream S.aurata in a commercial hatchery through application of different live food regimes.

\section{MATERIALS AND METHODS}

This study was undertaken in the Governmental Marine Finfish Hatchery, Km21, Alexandria, at the General Authority for Fish Resources Development, (GAFRD), Ministry of Agriculture, in order to study the effect of the rotifer Brachionus plicatilis and the encapsulated A. nauplii as a live food on survival rate and growth performance for gilthead sea bream $S$. aurata larvae. This experiment was performed in eight white circular fiberglass tanks, each of $1 \mathrm{~m} 3$ water volume in black greenhouse.

The Microalga Nannochloropsis oculata and the rotifer Brachionus rotundiformis were cultured in a greenhouse as a semi-continuous system (harvesting $20-30 \%$ daily), using fiberglass tanks of 250 and 500-liter capacity, respectively. A mixture of agricultural-grade fertilizer was the culture medium used for microalgae (1 liter of freshwater solution, containing $150 \mathrm{~g}$ ammonium sulfate, $25 \mathrm{~g}$ super phosphate, and $7.5 \mathrm{~g}$ urea, for 1000 liters of seawater added to the culture). Temperature range was $22-26^{\circ} \mathrm{C}$. One of the rotifer cultures received $100 \times 103$ microalgae cells per individual/day, while the other received $50 \times 103$ microalgae cells per individual/day and $0.5 \mu \mathrm{g}$ of baker's yeast per individual/day (rotifers were fed three different diets which represented the three treatments, with three replicates: treatment $\mathrm{A}$, rotifers fed only microalgae; treatment $\mathrm{B}$, rotifers fed microalgae and 
baker's yeast (1:1); treatment $C$, rotifers fed microalgae and baker's yeast (1:1) enriched with commercial emulsion, according to the manual of Oceanic Institute (1995). Rotifer enrichment was done with a commercial emulsion (Selco® from INVE Aquaculture NV, Basrode, Belgium), in 40-liter cylindric-conical tanks at a density of $400 \times 103$ individuals/liter over $15 \mathrm{~h}$ with $0.2 \mathrm{~g} / \mathrm{l}$ of the product, following manufacturer instructions. Artemia cysts collected from salt works at El-Max for salines Co. Alexandria, and incubated for $48 \mathrm{hrs}$ at $25 \mathrm{ppt}$ salinity to get good hatching ratio. The average diameter of artemia cysts was $254.5 \mu \mathrm{m}$ and the average length of its nauplii was $487.8 \mu \mathrm{m}$.

Two types of live foods the rotifer $B$. plicatilis and the encapsulated $A$. nauplii were tested in four treatments, 1) low level of rotifers and low artemia (LRLA) (control); 2) high level of rotifers and low level of artemia (HRLA); 3) low level of rotifers and high level of artemia (LRHA); and 4) high level of rotifers and high level of artemia (HRHA), (Low and high levels were 5, 25 and 50, 250 prey/ml rotifer and artemia respectively during the periods $1^{\text {st }}, 8^{\text {th }}, 9^{\text {th }}, 16^{\text {th }}, 17^{\text {th }}$ and $24^{\text {th }}$ days of the feeding experiment).

Approximately 30h after hatching, larvae of the Gilthead sea bream S. aurata were placed in one fiberglass tank $\left(1 \mathrm{~m}^{3}\right.$ liter). The tank was equipped with an airlifting system. Daylight fluorescent light provided a light intensity of 1000 lux at the water surface, with a photoperiod of $12 \mathrm{hr}$ light: $12 \mathrm{hr}$ dark (12L:12D). On the $20^{\text {th }}$ day after hatching, all surviving larvae were counted and 50 larvae were measured, using a dissecting microscope equipped with an mocular micrometer (standard average length and average body weight $7.3 \pm 0.20 \mathrm{~mm}$ and of $5.4 \pm 0.10 \mathrm{mg}$. Eight fiberglass tanks used of rearing larvae were stocked as a density of 1200 larvae /tank on 15 May 2007.

Water exchange was approximately 15\% per day. Temperature was monitored at 8:00 h daily, while salinity, ammonia, $\mathrm{pH}$ and dissolved oxygen were measured every six days, in tanks of each treatment. Temperature (21.3-26. $\left.{ }^{\circ} \mathrm{C}\right)$, non-ionized ammonia (0.07-0.10 mg/l), dissolved oxygen (4.0-5.5 mg/l), salinity (35 g/l) and pH (8.0) did not differ significantly among treatments.

Fish larvae used in the present experiment were produced from tank-matured brood stocks (4 years old and average weight of 750-1000g). Brood stocks were previously spawned artificially at a water temperature range from $16-18 \mathrm{C}^{\circ}$, using LHRH-hormone pellets.

Seawater (35 ppt) was pumped via a sand filter and passed through clothes' filter (200 micron) before being entered to the tanks. Water exchange rate was 40, 50, and $60 \%$ daily during the periods $1^{\text {st }}, 8^{\text {th }}, 9^{\text {th }}, 16^{\text {th }}, 17^{\text {th }}$ and $24^{\text {th }}$ days of the experiment, respectively. Each tank was equipped with standpipe fitted with Nylon screen (100 micron) to prevent the rotifers from escaping. Photoperiod was maintained at Light intensity during the experimental period of 200 lux, by installing 100-watt lamp over water surface, besides the fluorescent lamps hanged in the greenhouse. Tanks were siphoned once every day. A floating oil trap was used to remove the oil film on the water surface.

Nannochloropsis oculata was added to rotifers rearing tank at a density of 200.000 cells/ml during the experimental period. The rotifer Brachionus plicatilis was grown on the micro alga Nannochloropsis oculata while the rotifers were washed for 10 minutes before adding to larval rearing tanks.

At the end of the experiment, samples of 50 fish larvae were weighed and the average total length and weight in each treatment were measured to calculate the final weight, average daily length and gain, and specific growth rate (SGR \% in length and 
weight). Larval survival rate was calculated after 24 days through counting the total number of the produced fish. Measurements mentioned were calculated according to the following formula:

Fish survival rate $(\%)=100(\mathrm{FN} / \mathrm{IN})$

Where: FN: number of fish at the end of the experiment

IL: number of fish at the beginning of the experiment, (Akatsu et al., 1983)

Average daily length $(\mathrm{ADL})=(\mathrm{FL}-\mathrm{IL}) / \mathrm{T}$

Where: FL: mean length at the end of the experiment

IL: mean length at the beginning of the experiment

$\mathrm{T}$ : time in days

Average daily gain $(\mathrm{ADG})=(\mathrm{FW}-\mathrm{IW}) / \mathrm{T}$

Where: FW: mean weight at the end of the experiment

IW: mean weight at the beginning of the experiment

$\mathrm{T}$ : time in days

Specific growth rate in length $(\mathrm{SGR} \%)=100(\ln \mathrm{FL}-\ln \mathrm{IL}) / \mathrm{T}$

Where: FL: mean length at the end of the experiment

IL: mean length at the beginning of the experiment

$\mathrm{T}$ : time in days (Jauncey and Ross, 1982)

Specific growth rate in weight $($ SGR\%) $=100(\ln \mathrm{FW}-\ln \mathrm{IW}) / \mathrm{T}$

Where: FW mean weight at the end of the experiment

IW means weight at the beginning of the experiment

$\mathrm{T}$ : time in days ( Jauncey and Ross, 1982)

Condition factor $=100 *$ final weight $/(\text { total length })^{3}$

Water temperature and dissolved oxygen were measured daily, using oxygen meter (SPER Scientific), while $\mathrm{pH}$ values were recorded twice a week, using an advanced $\mathrm{pH}$ meter (840035 SPER Scientific). Water salinity was measured, using temperature compensated refractmeter.

Statistical analysis was performed using SPSS (Version 10 program) and treatments were evaluated at the 0.05 probability. Analyses of variance, one - way ANOVA was used to evaluate the effect of live food on survival rate, total body length and weight, average daily length and weight gain and Specific growth rate in length and weight. The differences within treatments using LSD were used at 0.05 probability (Steel and Torrie, 1980).

\section{RESULTS AND DISCUSSION}

Throughout the culture period, the averages of water quality criteria for larval rearing tanks was as follows: salinity $35 \mathrm{ppt}$; temperature $19.6 \mathrm{C}^{\circ}$; dissolved oxygen $\mathrm{DO}_{2} 6.9 \mathrm{ppm}$, and pH 8.02. Similar parameters have been reported by Zaki et al., (2003) and Nour et al., (2003).

Results in Table 1 show the effect of four different treatments of live food of a mixture of rotifers and artemia (LRLA, HRLA, LRHA and HRHA) on survival and growth performance of $S$. aurata larva. Survival rate \% of $S$. aurata larvae significantly $(\mathrm{P} \leq 0.05)$ increased from $12.17 \%$ with LRLA to $48.96 \%$ with HRHA. Higher concentrations of each of rotifers or arteria resulted in a better survival rate of $S$. aurata larva as compared with the control group (LRLA). However, the significant role of artemia over rotifers was clearly observed in the differences between the $2^{\text {nd }}(19.08)$ and $3^{\text {rd }}(32.21 \%)$ treatments respectively.

Growth performance of $S$. aurata larvae fed different combinations of live food (LRLA, HRLA, LRHA and HRHA) showed a significant $(\mathrm{P} \leq 0.05)$ increase in larval length and weight, length and weight gain, average daily length and weight and specific growth rate (SGR \%) in length and weight (Table 1). Growth in length showed the superiority of artemia (treatment HRLA) as a live food for $S$. aurata larvae over rotifers (treatment LRHA). While 
higher concentrations of both achieved a higher growth of length (treatment HRHA).On the other hand, growth in weight showed a similar trend in growth in length. Dhert et al. (1998) mentioned that there are three main critical and sensitive phases of larval age as follows: 1-the end of pre-larval stage (day 3-4), 2- the endo-exotroph stage (days 8-12), and 3-the larval stage (days 25-35). The results showed that when $S$. aurata larvae reach 5.0-5.2 mm (1520days after hatching), they start feeding on newly hatched rotifers and Artemia, while the most important factors affecting survival and growth of larvae in the hatcheries is the quantity and the quality of food during the most critical periods before weaning of larval fish until the complete formation of swim-bladder. One of the most important food items during this period is the rotifer Brachionus plicatilis (Dhert, 1996). This kind of natural food is very suitable for feeding many species of marine fishes, such as the sea bream Sparus aurata, sea bass Dicentrarachus labrax, halibut, turbot, sole, Red Sea bream, flat fish, clown fish, Japanese blue crab and the prawn Penaeus japonicus (Hoff and Snell, 1993). Crespo et al. (2001) mentioned that the nutritional factors, rather than infectious agents, are responsible for the high mortality encountered in the cultured dentex larvae. Rotifers has many advantages: 1- the possibility of rearing larvae at very high densities up to 2000 larvae / ml (Reitan et al., 1994); 2- tolerate a wide range of culture conditions; 3- have high reproduction rate; 4- of planktonic nature (Dhert, 1996), 5- with many sizes, to it suitable for many species and ages of fish and shrimp larvae, and 6-can be cultured on cheap formulated feeds. The results of Zaki et al. (2003) clearly show the importance of larvae survival and growth performance using the natural food organisms like rotifers). They concluded that 16 rotifers $/ \mathrm{ml}$ is the optimum density required for gilthead sea bream larvae during the $1^{\text {st }}$ to $21^{\text {st }}$ days of their life. That concentration of rotifers significantly $(\mathrm{P}<0.05)$ increased swim-bladder inflation, growth performance, survival rate and decreased malformations of the larvae. The authors found that about 1067 rotifers were required for each $1 \mathrm{~mm}$ increase in larval length during the period from the $2^{\text {nd }}$ to $21^{\text {st }}$ days of its life in an industrial commercial hatchery in Egypt.

The survival and growth rate of $S$. aurata larvae were greatly improved when high levels of rotifers were added together with artemia (treatment 4). The positive effect of artemia to $S$. aurata larvae during this stage of life appear to enhance appetite of the larvae. Ganzon-Naret (1994) reported that delaying feeding of artemia nauplii until day 15 resulted in slower growth rate of sea bass fed Artemia nauplii starting on day10. Further studies of the mechanisms and interactions between rotifer-larval and artemia larval interactions at various steps of the larval feeding process should be given high priority in future research. The present results clearly show that higher levels of rotifers and or artemia significantly $(\mathrm{P}<0.05)$ decreased the condition factor $(\mathrm{K})$ values from 0.71 to 0.57 respectively (Table 1 ).

Table 1: Effect of rotifers and artemia as a live food on survival rate and growth Performance of gilthead Sea bream, Sparus aurata larvae.

\begin{tabular}{|c|c|c|c|c|}
\hline \multirow[b]{2}{*}{ Items } & \multicolumn{4}{|c|}{ Treatments } \\
\hline & LRLA & HRLA & LRHA & HRHA \\
\hline \multicolumn{5}{|l|}{ a) Survival rate (\%) } \\
\hline Survival rate (\%) & $12.17^{\mathrm{d}}$ & $19.08^{\mathrm{c}}$ & $32.21^{\mathrm{b}}$ & $48.96^{\mathrm{a}}$ \\
\hline \multicolumn{5}{|l|}{ b) Growth in length } \\
\hline Initial length (mm/pce) & $7.30^{\mathrm{a}}$ & $7.30^{\mathrm{a}}$ & $7.30^{\mathrm{a}}$ & $7.30^{\mathrm{a}}$ \\
\hline Final length (mm/pce) & $11.50^{\mathrm{d}}$ & $12.80^{\mathrm{C}}$ & $14.30^{\mathrm{b}}$ & $15.65^{\mathrm{a}}$ \\
\hline Length gain (mm/pce) & $4.20^{\mathrm{d}}$ & $5.50^{c}$ & $7.05^{b}$ & $8.35^{\mathrm{a}}$ \\
\hline ADL (mm/pce/day) & $0.18^{\mathrm{d}}$ & $0.23^{\mathrm{c}}$ & $0.29^{\mathrm{b}}$ & $0.35^{\mathrm{a}}$ \\
\hline SGR in length (\%/day) & $1.89^{\mathrm{C}}$ & $2.34^{\mathrm{bc}}$ & $2.80^{\mathrm{ab}}$ & $3.27^{\mathrm{a}}$ \\
\hline \multicolumn{5}{|l|}{ c) Growth in weight } \\
\hline Initial weight (mg/pce) & $5.40^{\mathrm{a}}$ & $5.40^{\mathrm{a}}$ & $5.40^{\mathrm{a}}$ & $5.40^{\mathrm{a}}$ \\
\hline Final weight (mg/pce) & $10.85^{\mathrm{d}}$ & $13.75^{\mathrm{c}}$ & $18.15^{\mathrm{b}}$ & $21.95^{\mathrm{a}}$ \\
\hline Weight gain (mg/pce) & $5.45^{\mathrm{d}}$ & $8.35^{\mathrm{c}}$ & $12.75^{b}$ & $16.55^{\mathrm{a}}$ \\
\hline ADG (mg/pce/day) & $0.23^{\mathrm{d}}$ & $0.35^{\mathrm{c}}$ & $0.53^{\mathrm{b}}$ & $0.69^{\mathrm{a}}$ \\
\hline SGR in weight (\%/day) & $2.91^{\mathrm{d}}$ & $3.89^{c}$ & $5.05^{b}$ & $5.84^{\mathrm{a}}$ \\
\hline \multicolumn{5}{|l|}{ d) Condition factor (\%)3 } \\
\hline Condition factor(\%) & 0.71 & 0.66 & 0.62 & 0.57 \\
\hline
\end{tabular}

LRLA =low rotifers and low artemia; HRLA = high rotifers and

low artemia; LRHA = low rotifers and high artemia;

HRHA = high rotifers and high artemia.

Low rotifers $=5 \mathrm{pcs} / \mathrm{ml}$; high rotifers $=25 \mathrm{pcs} / \mathrm{ml}$

Low artemia $=50$ : high artemia $=200 \mathrm{pcs} / \mathrm{ml}$

Means in the same row with different superscripts are significantly different $(\mathrm{p} \leq 0.05)$ 


\section{ACKNOWLEDGEMENT}

The authors' wishes to express our thanks to the stuff members in the Governmental Marine Finfish Hatchery, Km21, Alexandria of the General Authority for Fish Resources Development, (GAFRD), Ministry of Agriculture, Alexandria, Egypt for the facilities offered throughout this work.

\section{REFERENCES}

Akatsu, S.; Aal-Abdul-Elah K. M. and S.K.Teng. (1983). Effects of salinity and water temperature on the survival and growth of brown-spotted grouper larvae.J. World Mariculture Soc., 14: 624-635.

Blaxter, J. H. S. (1968). Light intensity, vision and feeding in young plaice. J. Exp. Mar. Biol. Ecol., (2):293-307.

Bottino, N.R.; Gennity, J.; Lilly, M.L.; Simmons, E. and Finne, G. (1980). Seasonal and nutritional effects on the fatty acids of three species of shrimp, Penaeus setiferus, $P$. aztecus and P. duorarum. Aquacult.,19:139-148.

Crespo, S.; Marine de Mateo, M.; Santa Maria, C. A.; Sala, R.; Grau, A. and Pastor E. (2001). Histopathological observations during larval rearing of common dentex Dentex dentex L. (Sparidae). Aquacult., 3:121- 132.

Dhert, P.H. (1996). Rotifers. Manuel on the production and use of live food for aquaculture. Lavens, P; Sorgelos, (eds.). FAO Fisheries Technical Paper, No. 361, Rome, FAO.295p.

Dhert, P.H.; Divanach, P.; Kentouri, M. and Sorgeloos, P. (1998). Rearing Techniques for Difficult Marine Fish Larvae. World Aquacult., pp. 48-55.

Dhert, P. H; Schoeters, K.; Vermeulen, P.; Sun, J.; Gao, S.; Shang, Z.; and P.Sorgeloos(1994). Production and evaluation of resting eggs of Brachionus plicatilis originating from the P. R. of China. In: Lavens, P.; E.Jaspers and I. Roelants (EDS), Larvi'95 Fish and Shellfish Larviculture Symposium. European Aquaculture Society, Special Publication, Gent, Belgium, 24:315-319.

Fernald,R.D. (1993). Vision. In: Evans, D. H., (ED.), The physiology of Fishes. CRC press. U. S. A. pp.161-190.

Ganzon-Naret, E. S. (1994). Effect of delayed feeding of Artemia salina and partial replacement by moina macrocopa on growth and survival of seabass, Lates calcarifer (Bloch), Larvae. The Israeli journal of Aquaculture-Bamidgeh 46 (1):48-52.

Garcia, G. V. H. (1997). Morphological abnormalities in hatchery-bred milkfish Chanos chanos Forsskal fry and juveniles. Aquaculture, 152 (1-4): 155-166.

Gavaia, P. J.; Dinis, M. T. and Cancela, M. L. (2002). Osteological development and abnormalities of the vertebral column and caudal skeleton in larval and juvenile stages of hatchery-reared Senegal sole Solea senegalensis. Aquacult., 211(1-4): 305-323.

Heming,T. A. and Buddington, R. K. (1988). Yolk absorption in embryonic and larval fishes. In: Hoar. W.S., Randall, D. J. (Eds.) Fish Physiology. Academic Press, London, XI, pp. 407-446.

Hoff, F.H. and T.W. Snell, (1993). Plankton Culture Manual, Third Edition, Florida Aqua Farms. Florida, USA, May (1993).

Hunter,J.R.,(1981).Feeding ecology and predation of marine fish larvae. In: R.Lasker, Marine fish larvae, morphology, ecology and relation to fisheries. University of Washington Press. Seattle and London, pp.33-77. 
Jaunccey, K. and Ross, B. (1982). A Guide for Tilapia Feeds and Feeding. Institute of Aquaculture, University of Stirling, Scotland. UK.111pp.

Kolkovski, S.; Koven, W. and Tandler, A. (1997). The mode of action of Artemia in enhancing utilization of microdiet by gilthead seabream Sparus aurata larvae. Aquacult., 155:193-205.

Kolkovski, S.; Arieli, A.; Tandler, A. (1996a). Visual and chemical cues stimulate microdiet ingestion in gilthead seabream, Sparus aurata larvae. Aquaculture. Int., (in press).

Kuhlmann, D.; Quanrz, G. and Witt, U. (1981). Rearing of turbot larvae (Scophthalmus maximus L.) on culture food organisms and postmetamorphosis growth on natural and artificial food. Aquacult., 23(1/4):183-196.

Lagos, P. J. (1989). Pages 1175-1181 in Aquaculture-a Biotechnology in Progress. (N. De Paum, E Jaspers, H. Ackefors, N Wilkins, Eds.) Special Publication, European Aquaculture Society, Bredene, Belgium.1122pp.

Leger, P.; Bengtson, D. A.; Simpson, K. I. and Sorgeloos, P. (1986). The use and nutritional value of Artemia as a food source. Oceanogr. Mar. Biol. Ann. Rev. 24:521-623.

Lubzens, E. (1987). Raising rotifers for use in aquaculture. Hydrobiologia 147: 245-255.

Maneewong, S.; Ruangpanit, N.; Tattanon, T. and Kraisingdecha, P. (1986a). Experiment on rearing fry of sea bass (Lates calcarifer), from 1 to 12 days old at different densities. In: Report of Thailand and Japan Joint Coastal Aquaculture Research Project, Apr. 1984-Jan .1986, 2:20-22.

Maneewong, S.; Ruangpanit, N.; Tattanon, T. and Kraisingdecha, P. (1986b). Experiment on rearing fry of sea bass, (Lates calcarifer), from 13 to 29 days old at different densities. In: Report of Thailand and Japan Joint Coastal Aquaculture Research Project, Apr.1984-Jan .1986, 2: 23-26.

Nour, A. A.; Zaki; M. A.; Abdel-Rahim, M. M. and Mabrouk, H.A. (2003). Factors affecting swim-bladder inflation, survival, and growth performance of gilthead seabream Sparus aurata larvae:2-water salinity. Bull. Nat. Inst. Oceanogr. and Fish., ARE (in press).

Oceanic Institute (1995). Finfish hatchery manual, Maryut, Egypt. The Oceanic Institute Makapuu Point, P.O.BOX 25280, Honolulu, Hawaii 96825.

Reitan, K.I.; Rainuzzo, J. R. and Olsen, Y. (1994). Influence of lipid composition of live feed on growth, survival and pigmentation of turbot larvae. Aquaculture international, 2:33-48.

Sorgeloos, P. (1980). The use of the brine shrimp in aquaculture. In: the brine shrimp Artemia. Volume 3: Ecology, Culturing and use in Aquaculture. Universal press. Wetteren. Belgium, pp.25-46.

Steel, R. G. and Torrie, J. H. (1980). Principles and Procedures of Statistics: A Biomedical Approach, $2^{\text {nd }}$ ed. p.633. McGraw Hill, New York.

Van Stappen, G. and Sorgeloos, P. (1993). The cosmopotion brine shrimp.Infofish international, 4:45-50.

Watanabe, T.; Oowa, F.; Kitajima, C. and Fujita, S. (1980).Relationship between dietary values of brine shrimp Artemia salina and their content of w-3 highly unsaturated fatty acid. Nippon Suisan Gakkaishi, 46:35-41.

Zaki, M.A.; Nour, A.A.; Abdel-Rahimand, M. M.; Mabrouk, H. A. (2003). Factors affecting swim-bladder inflation, survival, and growth performance of gilthead seabream Sparus aurata larvae (1): Rotifers brachionus plicatilis consumption. Bull. Nat. Inst. Oceanography and Fish., ARE (in press). 


\section{ARABIC SUMMARY}

تأثير استخدام الروتيفر والارتيميا على معدلات البقاء وكفاءة النمو ليرقات اسماك الدنيس

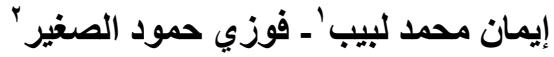

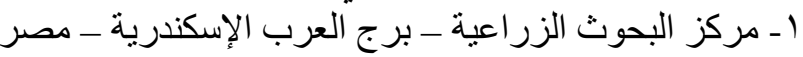

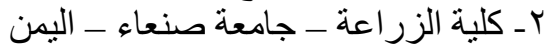

نفذت هذه التجربة لدر اسة تأثير الغذاء الطبيعي من الروتيفر والارتيميا على معدل الإعاثتة وكفاءة

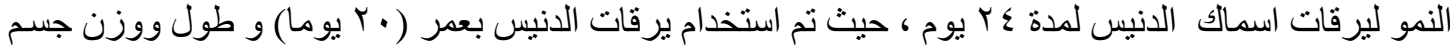

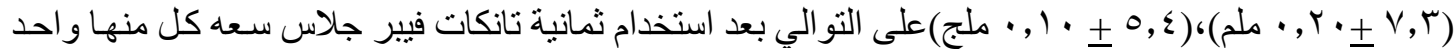

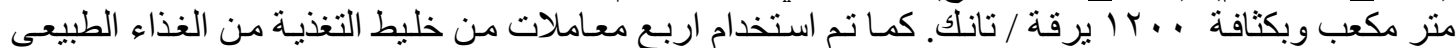

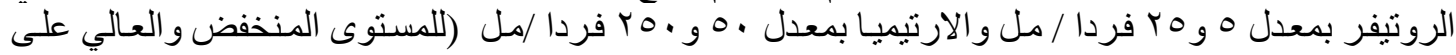

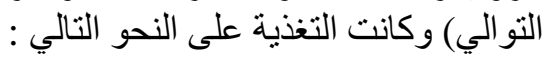

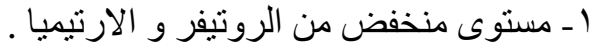

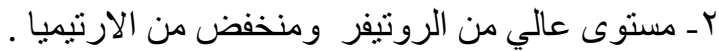

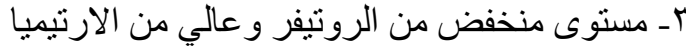

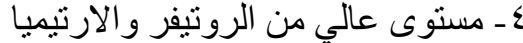

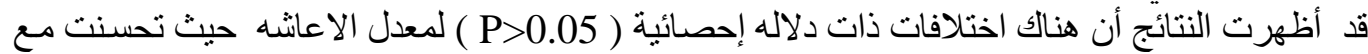

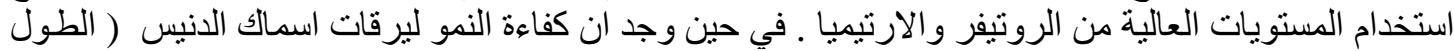

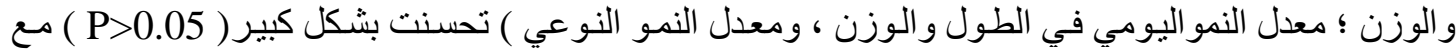

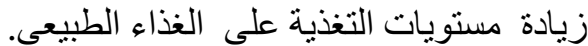

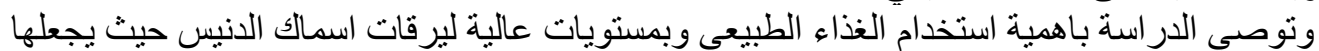
متاحة امام اليرقات في هذه المرحلة من العمر. 